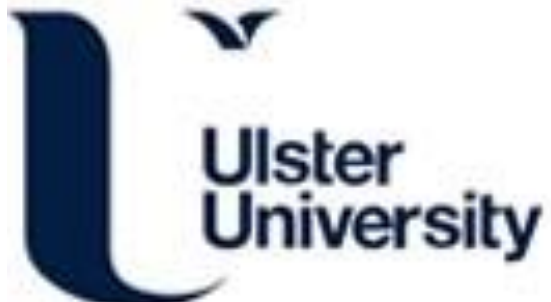

\section{An universally calibrated microplate ferric reducing antioxidant power (FRAP) assay for foods and applications to Manuka honey}

Bolanos de la Torre, A. A. S., Henderson, T., Singh Nigam, P., \& Owusu-Apenten, R. K. (2015). An universally calibrated microplate ferric reducing antioxidant power (FRAP) assay for foods and applications to Manuka honey. Food Chemistry, 174(1), 119-123. https://doi.org/10.1016/j.foodchem.2014.11.009

Link to publication record in Ulster University Research Portal

\section{Published in:}

Food Chemistry

Publication Status:

Published (in print/issue): 01/05/2015

DOI:

10.1016/j.foodchem.2014.11.009

\section{Document Version}

Author Accepted version

\section{General rights}

Copyright for the publications made accessible via Ulster University's Research Portal is retained by the author(s) and / or other copyright owners and it is a condition of accessing these publications that users recognise and abide by the legal requirements associated with these rights.

\section{Take down policy}

The Research Portal is Ulster University's institutional repository that provides access to Ulster's research outputs. Every effort has been made to ensure that content in the Research Portal does not infringe any person's rights, or applicable UK laws. If you discover content in the Research Portal that you believe breaches copyright or violates any law, please contact pure-support@ulster.ac.uk. 


\section{Accepted Manuscript}

Universally calibrated microplate ferric reducing antioxidant power (FRAP) assay for foods and applications to Manuka honey

Amparo Angelica S. Bolanos de la Torre, Terence Henderson, Poonam Singh Nigam, Richard K. Owusu-Apenten

PII: S0308-8146(14)01734-8

DOI: http://dx.doi.org/10.1016/j.foodchem.2014.11.009

Reference: FOCH 16690

To appear in:

Food Chemistry

Received Date:

20 July 2014

Revised Date: 25 October 2014

Accepted Date: 1 November 2014

Please cite this article as: Bolanos de la Torre, A.A.S., Henderson, T., Singh Nigam, P., Owusu-Apenten, R.K., Universally calibrated microplate ferric reducing antioxidant power (FRAP) assay for foods and applications to Manuka honey, Food Chemistry (2014), doi: http://dx.doi.org/10.1016/j.foodchem.2014.11.009

This is a PDF file of an unedited manuscript that has been accepted for publication. As a service to our customers we are providing this early version of the manuscript. The manuscript will undergo copyediting, typesetting, and review of the resulting proof before it is published in its final form. Please note that during the production process errors may be discovered which could affect the content, and all legal disclaimers that apply to the journal pertain. 
Revised: FOODCHEM-D-14-03339

Universally calibrated microplate ferric reducing antioxidant power (FRAP) assay for foods and applications to Manuka honey

Amparo Angelica. S. Bolanos de la Torre ${ }^{1}$, Terence Henderson, Poonam Singh Nigam \& Richard K. Owusu-Apenten*

School of Biomedical Sciences, Faculty of Life and health sciences, Ulster University, Cromore Road, Coleraine BT52 1SA

${ }^{*}$ Corresponding author:

Dr Richard Owusu-Apenten

School of Biomedical Sciences, Faculty of Life and health sciences, Ulster University, Cromore Road,

Coleraine BT52 1SA

Email: r.owusu-apenten@ulster.ac.uk

Tel: (0)44028 70124314

${ }^{1}$ Permanent address: ONIRIS. Ecole Nationale Vétérinaire, Agroalimentaire et de l'alimentation de Nantes-Atlantique. Site de la Géraudière : rue de la Géraudière BP 8222544322 Nantes cedex 3, France 


\section{Abstract}

The ferric reducing antioxidant power (FRAP) assay was recently adapted to a microplate format. However, microplate-based FRAP (mFRAP) assays are affected by sample volume and composition. This work describes a calibration process for mFRAP assays which yields data free of volume effects. From the results, the molar absorptivity (ع) for mFRAP assay was $141698 \mathrm{M}^{-1} \mathrm{~cm}^{-1}$ for gallic acid, $49328 \mathrm{M}^{-1} \mathrm{~cm}^{-1}$ for ascorbic acid, and $21606 \mathrm{M}^{-1} \mathrm{~cm}^{-1}$ for ammonium ferrous sulphate. The significance of $\varepsilon\left(\mathrm{M}^{-1} \mathrm{~cm}^{-1}\right)$ is discussed in relation to mFRAP assay sensitivity, minimum detectable concentration, and the dimensionless FRAP-value. Gallic acid showed 6.6 moles of $\mathrm{Fe}^{2+}$ equivalents compared to 2.3 moles of $\mathrm{Fe}^{+2}$ equivalents for ascorbic acid. Application of the mFRAP assay to Manuka honey samples (rated 5+, 10+, 15+, and 18+ Unique Manuka Factor; UMF) showed that FRAP values $\left(0.54-0.76 \mathrm{mmol} \mathrm{Fe}^{2+}\right.$ per $100 \mathrm{~g}$ honey) were strongly correlated with UMF ratings $\left(R^{2}=0.977\right)$ and total phenols content $\left(R^{2}=0.982\right)$ whilst the UMF rating was correlated with the total phenols $\left(\mathrm{R}^{2}=0.999\right)$. In conclusion, mFRAP assay results were successfully standardized to yield data corresponding to $1-\mathrm{cm}$ spectrophotometer which is useful for quality assurance purposes. The antioxidant capacity of Manuka honey was found to be directly related to the UMF rating (199 words)

Keywords:

Antioxidant capacity, microplate assay, ferric reducing antioxidant power, FRAP, Manuka honey 


\section{Highlights:}

Universal calibrations for microplate FRAP assays

Simplified pathlength corrections for microplate FRAP assay

Microplate assay for total antioxidant capacity

Manuka honey FRAP value

Manuka UMF rating predicts total phenols content

\section{List of chemical compounds (PubChem CID)}

2, 4, 6-Tripyridyl-s-Triazine (PubChem CID 77258)

Ammonium ferrous sulphate (PubChem CID 197097)

Ascorbic acid (PubChem CID 54670067)

Gallic acid (PubChem CID 370) 


\section{Introduction}

The ferric reducing antioxidant power (FRAP) assay now in its $18^{\text {th }}$ year (Benzie \& Strain, 1996; Benzie \& Strain, 1999a) monitors the reaction of $\mathrm{Fe}^{2+}$ with 2, 4, 6Tripyridyl-s-Triazine (TPTZ) to form a violet-blue colour with an absorbance maximum at 593nm (Collins, Diehl \& Smith, 1959). Some FRAP assays employ phenanthroline, batho-phenanthrolin, ferricyanide or ferrozine as a chromogenic ligand (Berker, Guclu, Tor \& Apak, 2007). However, all FRAP assays detect compounds with a standard reduction potential $\left(\mathrm{E}^{\mathrm{O}}\right)$ below +0.77 and which reduce $\mathrm{Fe}^{3+}$ to $\mathrm{Fe}^{2+}$ (Benzie et al., 1996; Benzie et al., 1999a). The characteristics of the TPTZ-FRAP assay have been compared with other total antioxidant capacity (TAC) assays (Benzie \& Choi, 2014; Fraga, Oteiza \& Galleano, 2014; Gulcin, 2012; Huang, Ou \& Prior, 2005; Magalhaes, Segundo, Reis \& Lima, 2008; Moon \& Shibamoto, 2009). FRAP assays are compatible with auto-analyser and manual assay formats (Benzie et al., 1996; Benzie et al., 1999a). Databases containing thousands of FRAP-values for plant foodstuffs have been compiled (Carlsen et al., 2010; Halvorsen et al., 2006).

Microplate-based FRAP (mFRAP) assays were introduced recently leading to improved sample throughput compared to the manual FRAP assay (Jimenez-Alvarez et al., 2008; Firuzi, Lacanna, Petrucci, Marrosu \& Saso, 2005; Tsao, Yang \& Young, 2003). However, the optical pathlength for microplate readers is not fixed and results may be affected by changes of sample volume and composition (Lampinen, Raitio, Perälä, Oranen \& Harinen, 2012; Smith, Morris \& Levander, 2001). Most microplate readers are lacking the automated photometric pathlength correction (PPC) facility found in more expensive models (Smith et al., 2001). The pathlength dependence on sample 
volume leads to microplate results being less readily compared between different laboratories.

The molar absorptivity $\left(\varepsilon, \mathrm{M}^{-1} \mathrm{~cm}^{-1}\right)$ for the manual FRAP assay was evaluated recently for a $1 \mathrm{~cm}$-pathlength spectrophotometer with ammonium ferrous sulphate (AFS) as standard (Hayes, Mills, Neville, Kiddie \& Collins, 2011; Stratil, Klejdus \& Kuban, 2006). In principle, the molar absorptivity represents a universal calibration parameter for different compounds, and could be used for quality assurance and for comparing FRAP assays from different laboratories (Hayes et al., 2011). Currently, there are limited reports for the molar absorptivity value for FRAP assays of food antioxidants (Pulido, Bravo \& Saura-Calixto, 2000; Stratil et al., 2006). To our knowledge, few or no molar absorptivity values have been reported for the mFRAP format and so the quality of assays cannot be evaluated.

In this paper, we describe a process for normalizing microplate results to match data obtainable a 1-cm pathlength spectrophotometer. The pathlength correction is applied to two mFRAP assays to determine the molar absorptivity and related parameters for ascorbic acid and gallic acid as calibration standards. As part of ongoing research, the mFRAP assay was applied to evaluate honey samples of different Unique Manuka Factor (UMF) ratings and the findings compared with values of the total phenols content for the same samples. The outcomes showed that the mFRAP assays can yield accurate data independent of sample volume effects. The described calibration method is inexpensive and should be easy to implement for other microplatebased assays for the purpose of quality assurance. The antioxidant capacity of Manuka honey was found to be directly related to the UMF rating. 


\section{Materials and methods}

All reagents were purchased from Sigma Aldrich and used as received. Colorimetric measurements were recorded using a UV/Visible spectrophotometer (Ultrospec 2000, Pharmacia Biotech, Uppsala Sweden) in conjunction with 1-cm polystyrene cuvettes (Sarsted Ltd, Leicester, UK). Microplate assays involved a 96-microplate reader (VERSAmax; Molecular devices, Sunnydale, California, USA) used with flat-bottomed 96-well microplates (NUNC, Sigma Aldrich, UK). FRAP solutions were prepared as described previously (Benzie et al., 1996; Benzie et al., 1999a). The FRAP workingsolution was prepared by mixing 10-volumes of acetate buffer ( $300 \mathrm{mM}, \mathrm{pH} 3.6$ ) with 1volume of TPTZ $(40 \mathrm{mM}$ dissolved with $40 \mathrm{mM} \mathrm{HCl})$ and 1-volume of ferric chloride (20 $\mathrm{mM}$ in water). The FRAP working solution was prepared daily and warmed at $37^{\circ} \mathrm{C}$ for 10 minutes before use. Ascorbic acid and AFS standards (1000 $\mu \mathrm{M})$ were prepared in $100 \mathrm{ml}$ volumetric flasks using double deionized water and with no other precautions. Gallic acid $(1000 \mu \mathrm{M})$ was prepared by pre-diluting $17 \mathrm{mg}$ solid with $10 \mathrm{ml}$ methanol and making up to $100 \mathrm{ml}$.

Manuka honey samples (rated $+5,+10,+15,+18$ Unique Manuka Factor; UMF) were purchased from Comvita Ltd (Berkshire, UK). A batch of Scottish Heather Honey (assumed UMF of +0 ) was purchased from Rowse Honey Ltd (London, UK). All samples of honey were stored at room temperature and diluted $1 / 10$ with distilled water before analysis. The total antioxidant capacity for honey samples was determined using the mFRAP1 method as described for ferric sulphate standard (see below). The total phenol content for honey samples was measured using the Folin Dennis method and 
expressed as a Gallic Acid Equivalent per Kg product (GAE mg/Kg) as outlined by (Singleton, Orthofer, \& Lamuela-Raventos 1999).

For a manual FRAP assay $75 \mu \mathrm{l}$ of sample $(0,125,250,500,1000 \mu \mathrm{M})$ was added to $1.5 \mathrm{ml}$ micro-centrifuge tubes followed by $1425 \mu \mathrm{l}$ of working FRAP solution. The mixtures were incubated in the dark for 30 minutes at $37{ }^{\circ} \mathrm{C}$ and absorbance readings were recorded at $593 \mathrm{~nm}$ (A593) using 1 cm-pathlength spectrophotometer. To perform the microplate FRAP assay version \#1 (mFRAP1) we completed a manual FRAP assay as above. Thereafter $200 \mu \mathrm{l} x 4$ portions of the reaction mixture were transferred to a 96-well microplate for A593 measurement. Microplate FRAP assay version \#2 (mFRAP2) was performed according to previous reports with minor modifications (Jimenez-Alvarez et al., 2008; Firuzi et al., 2005; Tsao et al., 2003). Sample solutions $(20 \mu \mathrm{l})$ were added directly to the 96-well microplate followed by 280 $\mu \mathrm{l}$ of working FRAP solution. The mixtures were shaken, incubated at $37{ }^{\circ} \mathrm{C}$ in the dark for 30 minutes and then A593 readings were recorded using a microplate reader. All experiments were run at least twice on two different days.

\section{Results and Discussion}

The FRAP assay, which is one of the most widely cited assays for total antioxidant capacity, was recently adapted to microplate assay format. However, microplate FRAP assay have not been properly calibrated so that universal calibration parameters have not been determined for the purpose of quality control. Currently microplate based FRAP assays are used for comparative analysis of samples for which absolute calibration parameters are not essential. On the contrary, determination of absolute 
calibration parameters will help identify where particular implementations of the FRAP assays are dogged by systematic error. Access to absolute calibration parameters is also essential to compare assay performance across different platforms, e.g. the autoanalyzer compared with the standardized $1-\mathrm{cm}$ platform (Sochor, Ryvolova, Krystofova, Salas, Hubalek et. al., 2010). In this paper we describe a method for the determination of calibration parameters for microplate-based FRAP (mFRAP) assays which are free from volume effects. The FRAP assay, one of the most widely cited assays for total antioxidant capacity, was recently adapted to microplate assay format. However, microplate FRAP assay have not been properly calibrated so that universal calibration parameters have not been determined for the purpose of quality control. Manuka honey is a mono-floral honey, produced by bees foraging on the Manuka tree (Leptospermum scoparium). Previous research demonstrated that Manuka honey possess antimicrobial activity. Though the mode of action of Manuka honey remains under discussion current evidence suggests that antioxidant components may contribute to their bioactivity (Weston 2000, Snow \& Manley 2004; Kwakman, Velde, de Boer, Vandenbroucke-Grauls, 2011).

We assume that all FRAP formats conform to Beer's law over a defined concentration (C);

$$
\begin{aligned}
& A 593=\varepsilon \underline{L} C \\
& A 593=\varepsilon \underline{L}^{\prime} C
\end{aligned}
$$

where A593 is absorbency at $593 \mathrm{~nm}, \varepsilon$ is the true molar absorptivity $\left(\mathrm{M}^{-1} \mathrm{~cm}^{-1}\right), L$ is the light pathlength $(1-\mathrm{cm})$ for a $1-\mathrm{cm}$ spectrophotometer, and L' is the corresponding light pathlength in a microplate reader. From (1) and (2) plotting A593 vs. C will produce 
straight-line graphs $(Y=m x)$ with a gradient $(m)$ equal to $\underline{\varepsilon . L}$ for spectrophotometric assay or $\underline{\varepsilon . L^{\prime}}$ for microplate analysis. Since $L^{\prime}<L$, the absorptivity $\left(\varepsilon^{\prime}=\varepsilon . L^{\prime}\right)$ using a plate reader will be numerically lower compared to values from a $1-\mathrm{cm}$ spectrophotometer. Measuring the molar absorptivity value for mFRAP assays could be useful for quality assurance and for comparing assays from different laboratories (Hayes et al., 2011).

To normalize mFRAP data for $1-\mathrm{cm}$ pathlength we performed a separate manual FRAP assay using AFS as a calibration standard and a $1-\mathrm{cm}$ path length instrument for A593 measurements. The method is simple and accessible for most laboratories. A graph of A593 vs. concentration produced a straight-line graph $\left(R^{2}=0.9992\right)$. According to the gradient of this graph $(\varepsilon L)$ the molar absorptivity using AFS standard was $21423( \pm 204) \mathrm{M}^{-1} \mathrm{~cm}^{-1}$ which compares with $19800 \mathrm{M}^{-1} \mathrm{~cm}^{-1}, 21140 \mathrm{M}^{-1} \mathrm{~cm}^{-1}, 21500$ or $22600 \mathrm{M}^{-1} \mathrm{~cm}^{-1}$ in the literature (Collins et al., 1959; Hayes et al., 2011; Issopoulos \& Salta, 1997; Stratil et al., 2006).

When AFS solutions were analysed by the mFRAP1 assay (200 $\mu$ lotal volume) the apparent molar absorptivity was $10509( \pm 46)$ and consequently the effective optical pathlength $\left(L^{\prime}=10509 / 21423\right)$ was $0.49 \mathrm{~cm}$. For the mFRAP2 analysis of AFS $(20 \mu \mathrm{l}$ sample and $300 \mu$ l total assay volume) the graph of A593 vs. concentration yielded an apparent molar absorptivity $\left(\varepsilon^{\prime}\right)$ of $18065( \pm 36) \mathrm{M}^{-1} \mathrm{~cm}^{-1}$ and consequently, the instrument pathlength was determined as $\left(L^{\prime}=\varepsilon^{\prime} / \varepsilon .=18065 / 21423=\right) 0.83 \mathrm{~cm}$. Table 1 shows a summary of such results alongside of the apparent absorptivity values for ascorbic acid and gallic acid. 
In an attempt to confirm above results, optical pathlength values were also calculated. Assuming each microplate well is perfectly cylindrical with a radius $(r)$ the optical pathlength $L^{\prime}(\mathrm{cm})=\mathrm{V} /\left(n \cdot \mathrm{r}^{2}\right)$ where $\mathrm{V}\left(\mathrm{cm}^{3}\right)$ is the total assay volume. Actually, the flat-bottomed 96-microwell plates used in this study had conical-shaped wells with a wider cross sectional area at the apex $($ diameter $=0.689 \mathrm{~cm})$ compared to the bottom (diameter $=0.635 \mathrm{~mm}$ ) and so we used $0.662 \mathrm{~cm}$ as the average well diameter. Figure 1 shows that the calculated pathlength increases linearly with the filling volume per well. Where $V$ is equal to $0.3 \mathrm{~cm}^{3}$ or $0.2 \mathrm{~cm}^{3}$ the predicted optical pathlength was $0.87 \mathrm{~cm}$ or $0.58 \mathrm{~cm}$, respectively. Such values deviate by $+4.8 \%$ and $+18.4 \%$ from the pathlengths determined from colorimetric measurements (Table 1). Errors arising from the calculated pathlengths are more substantial with low filling volumes. Differences between the calculated and actual pathlengths for microplate readers can be expected also because differences in sample composition as well as volume can affect the height of the meniscus formed within microplate wells (Lampinen et al., 2012; Smith et al., 2001).

Some high-end microplate readers are fitted with an automatic PPC facility which normalizes microplate output so that it matches values achievable with $1-\mathrm{cm}$ pathlength spectrophotometer (Lampinen et al., 2012; Smith et al., 2001). Instrumental PPC employ infra-red measurements taken at $900 \mathrm{~nm}$ and $975 \mathrm{~nm}$ to determine the height of water within each well. Absorbance readings are then adjusted to $1-\mathrm{cm}$ pathlength according the height of fluid detected, on a well-by-well basis. PPC can correct for wellto-well differences in pipetting volume, improve assay precision, and enable the direct calculation of analyte concentration using Beer's law (Lampinen et al., 2012). 
Figure 2 shows calibration graphs for mFRAP2 assay with AFS, gallic acid, or ascorbic acid prior to pathlength correction. The concentrations plotted in Figure 2 were adjusted for sample dilution. Table 1 shows calibration parameters for mFRAP1 and mFRAP2 assays without and with pathlength correction.

The average value for $\varepsilon\left(\mathrm{M}^{-1} \mathrm{~cm}^{-1}\right)$ using the mFRAP1 and mFRAP2 assays was $141698 \mathrm{M}^{-1} \mathrm{~cm}^{-1}$ for gallic acid, $49328 \mathrm{M}^{-1} \mathrm{~cm}^{-1}$ for ascorbic acid, and $21606 \mathrm{M}^{-1} \mathrm{~cm}^{-1}$ for AFS. There are no published microplate based molar absorptivity values for food antioxidants for comparison (Tsao et al., 2003). However, Pulido et al (2000) reported the molar absorptivity for a manual FRAP assay as $113900 \mathrm{M}^{-1} \mathrm{~cm}^{-1}, 46580 \mathrm{M}^{-1} \mathrm{~cm}^{-1}$, or $14620 \mathrm{M}^{-1} \mathrm{~cm}^{-1}$ for gallic acid, ascorbic acid and ferrous sulphate, respectively. Stratil and co-workers found absorptivity values of $100500 \mathrm{M}^{-1} \mathrm{~cm}^{-1}$ for gallic acid, $28200 \mathrm{M}^{-1}$ $\mathrm{cm}^{-1}$ for ascorbic acid and $19800 \mathrm{M}^{-1} \mathrm{~cm}^{-1}$ for AFS (Stratil et al., 2006). The literature values for gallic acid and ascorbic acid are lower than values for the mFRAP assay whereas $\mathrm{Fe}^{2+}$ values agree well. One possible reason for differences in results may be that the previous reactions were performed over a restricted time-frame and did not go fully to completion (Stratil et al., 2006).

The molar absorptivity is related to the FRAP-value ( $\mu \mathrm{M} \mathrm{Fe}{ }^{+2}$ equivalents), which is a common empirical index of antioxidant capacity of food compounds. Typically, the FRAP-value is determined using a "single-point" calibration performed with a fixed concentration of $\mathrm{AFS}, \mathrm{C}_{\mathrm{f}}(\mu \mathrm{M})$ in accordance with equation (3);

$$
\text { FRAP value }(\mu \mathrm{M})=\mathrm{C}_{\mathrm{f}} \text { *A593 Test } / \mathrm{A} 593_{\mathrm{Fe} 2+}
$$

where "Test" and "Fe ${ }^{2+”}$ refer to values for the test compound and for AFS standard solution, respectively. Typically, the FRAP-value is also adjusted for a unit mass (e.g., 
per gram) of food sample (Carlsen et al., 2010; Halvorsen et al., 2006). The A593 term from equation (3) can be substituted with molar absorptivity (equation 1) followed by rearrangement to yield a dimensionless FRAP value (equation 4);

$$
\text { FRAP-value } / C_{f}=\varepsilon \text { Test } / \varepsilon \cdot \mathrm{Fe}^{2+}=\text { A593 Test } / \text { A593 Fe2+ }
$$

In fact, the dimensionless FRAP-value describes $\mathrm{Fe}^{2+}$ equivalents- or the number of moles of ferric $\left(\mathrm{Fe}^{2+}\right)$ ions produced by one mole of antioxidant during the FRAP assay (Halvorsen, \& Blomhoff, 2011). To determine the dimensionless FRAP-value both the test-compound and the AFS are analysed at the same molar concentration $\left(\mathrm{C}_{\mathrm{f}}\right)$.

According to results from the present study (Table 1) and eqn. 4, gallic acid has a dimensionless FRAP-value of $6.5 \mathrm{Fe}^{2+}$ equivalents whilst ascorbic acid has a FRAP response equal to $2.3 \mathrm{Fe}^{2+}$ equivalents. Previous investigations found that ascorbic acid, $\alpha$-tocopherol and uric acid had a "relative FRAP activity" of 2.0 units compared to 1 unit for ferrous sulphate. One mole bilirubin was found to reduce 4 moles of $\mathrm{Fe}^{3+}$ to $\mathrm{Fe}^{2+}$. The $\mathrm{Fe}^{2+}$ equivalents for serum albumin was 0.1 so that 10 -moles of protein were required reduce one mole of $\mathrm{Fe}^{3+}$ to $\mathrm{Fe}^{2+}$ (Benzie \& Strain 1996, 1999). Other investigations found that one mole of gallic acid reacts with 6.6-7.8 moles $\mathrm{Fe}^{3+}$ but ascorbic acid reacts with 1.2-2.0 molecules of $\mathrm{Fe}^{3+}$ during the manual FRAP assay (Pulido et al., 2000; Stratil et al., 2006). The FRAP response for quercetin and tannin were consistent with 11-12 $\mathrm{Fe}^{2+}$ equivalents compared to 1.0 for resveratrol (Pulido et al., 2000; Stratil et al., 2006). Structure-activity studies showed that the FRAP-value for phenols was strongly correlated with their redox potential determined by cyclic voltammetry (Firuzi et al., 2005). 
The antimicrobial effects of medicinal honeys are attributed to a number of bioactive components e.g., hydrogen peroxide, bee defensins, methylglyoxal or polyphenols though the relative importance of these agents remains uncertain (Weston 2000, Snow \& Manley 2004). The peroxide free anti-microbial activity of Manuka honey is thought to be dependent on the levels of methylglyoxal and polyphenols (Kwakman, Velde, de Boer, Vandenbroucke-Grauls, 2011). In this study, we applied the mFRAP1 assay to five different honeys with different "Unique Manuka Factor" (UMF) ratings which shows the antiseptic activity of honey in terms of the equivalent percent solution of phenol (Molan 2008).

Table (2) shows the FRAP results for total antioxidant capacity of Manuka honey expressed as, $\mu \mathrm{M} \mathrm{Fe}{ }^{2+}$ per $10 \%$ honey (Jubri, Rahim, \& Aan 2013) or as mmol- $\mathrm{Fe}^{2+}$ per $100 \mathrm{~g}$ of honey (Carlsen et al. 2010). Table (2) also shows total phenols content (mg $\mathrm{GAE} / \mathrm{Kg}$ ) of Manuka honey samples and their UMF rating. The current estimates for total antioxidant capacity (Table 2) are up to 2-fold higher compared with results appearing in the literature for Manuka honey samples though previous studies did not report the UMF rating. For example, the FRAP value was $215.7( \pm 50) \mu \mathrm{M} \mathrm{Fe}{ }^{2+}$ per $10 \%$ honey with a total phenols content of $201( \pm 36) \mathrm{mg} \mathrm{GAE} / \mathrm{kg}$ (Jubri, et al. 2013 ). A comprehensive study of Malaysian honeys and Manuka honey by Moniruzzaman, Sulaiman, Khalil, \& Gan (2013) reported the FRAP value of $648( \pm 0.9) \mu \mathrm{M}$ Fe2+ $/ 100 \mathrm{~g}$ and total phenols value of $526( \pm 12) \mathrm{mg} \mathrm{GAE} / \mathrm{kg}$ for Manuka honey of undeclared UMF rating. In agreement with the cited investigations, we found the FRAP values for honeys were highly correlated with total phenols content $\left(R^{2}=0.982\right)$.

\section{(Table 2 here)}


The present study demonstrates also that FRAP values for Manuka honey are highly correlated with their UMF rating $\left(R^{2}=0.977\right)$. Moreover, the UMF value could be predicted from the total phenols content of Manuka honeys according to the straight-line equation; UMF $=0.065$ TP $-19.159\left(R^{2}=0.999\right)$, where TP is the total phenols content (mg-GAE/Kg honey). Apparently $99.9 \%$ and 97.7 of the UMF rating for the Manuka honey considered in this study can be accounted for in terms of changes of total phenols content and total antioxidant capacity, respectively. Finally, it is instructive to compare the FRAP values from Table (2) with values tabulated for 3100 foods, herbs, beverages, and supplements expressed on the basis of $\mathrm{mmol} \mathrm{Fe}{ }^{2+}$ per $100 \mathrm{~g}$ (Carlsen et al. 2010). Apparently, the total antioxidant capacity for Manuka honey samples are comparable to the FRAP values recorded for apple juice (0.27), cocoa drink with milk (0.37) and tomato juice (0.48).

In conclusion, this study demonstrated that microplate readers will underestimate the sensitivity for colorimetric analysis compared to data from a 1-cm pathlength spectrophotometer. However, the effective optical pathlength for a microplate reader can be readily determined under conditions not far removed those used for the mFRAP assay. The molar absorptivity values for gallic acid and ascorbic acid were determined clearly for the first time using the mFRAP format. Using the average calibration parameters for mFRAP1 and 2, the minimum detectable concentration and upper limit of linearity was $0.92 \times 10^{-7} \mathrm{M}$ and $250 \times 10^{-7} \mathrm{M}$ for gallic acid, respectively. For ascorbic acid the minimum detectable concentration and upper limit of linearity was $2.0 \times 10^{-7} \mathrm{M}$ and $\geq 670 \times 10^{-7} \mathrm{M}$, respectively. Analysis of New Zealand Manuka honey showed that the total antioxidant capacity is related to the UMF rating. The pathlength corrections 
described here should be applicable to other microplate based assays for total antioxidant capacity. The methodology detailed in the current could be useful in evaluating antioxidant assays on a variety of different platforms.

\section{Acknowledgement}

We are grateful for the School of Biomedical Sciences, for supporting this work.

\section{References}

Benzie, I. F., \& Choi, S. W. (2014). Antioxidants in food: content, measurement, significance, action, cautions, caveats, and research needs. Advances in Food \& Nutrition Research, 71, 1-53.

Benzie, I. F. F., \& Strain, J. J. (1996). The ferric reducing ability of plasma (FRAP) as a measure of "antioxidant power": The FRAP assay. Analytical Biochemistry, 239(1), 7076.

Benzie, I. F. F., \& Strain, J. J. (1999). Ferric reducing antioxidant power assay: Direct measure of total antioxidant activity of biological fluids and modified version for simultaneous measurement of total antioxidant power and ascorbic acid concentration. Oxidants and Antioxidants, Pt A, 299, 15-27.

Berker, K. I., Guclu, K., Tor, I., \& Apak, R. (2007). Comparative evaluation of Fe (III) reducing power-based antioxidant capacity assays in the presence of phenanthroline, 
batho-phenanthroline, tripyridyltriazine (FRAP), and ferricyanide reagents. Talanta, 72(3), 1157-1165.

Carlsen, M. H., Halvorsen, B. L., Holte, K., Bohn, S. K., Dragland, S., Sampson, L., Willey, C., Senoo, H., Umezono, Y., Sanada, C., Barikmo, I., Berhe, N., Willett, W. C., Phillips, K. M., Jacobs, D. R., \& Blomhoff, R. (2010). The total antioxidant content of more than 3100 foods, beverages, spices, herbs and supplements used worldwide. Nutrition Journal, 9, 11.

Collins, P., Diehl, H., \& Smith, G. F. (1959). 2,4,6-Tripyridyl-s-triazine as reagent for iron. Determination of iron in limestone, silicates, and refractories. Analytical Chemistry, 31(11), 1862-1867.

Firuzi, O., Lacanna, A., Petrucci, R., Marrosu, G., \& Saso, L. (2005). Evaluation of the antioxidant activity of flavonoids by "ferric reducing antioxidant power" assay and cyclic voltammetry. Biochimica Et Biophysica Acta-General Subjects, 1721(1-3), 174-184.

Fraga, C. G., Oteiza, P. I., \& Galleano, M. (2014). In vitro measurements and interpretation of total antioxidant capacity. Biochimica Et Biophysica Acta, 1840(2), 931934.

Gulcin, I. (2012). Antioxidant activity of food constituents: an overview. Archives of Toxicology, 86(3), 345-391.

Halvorsen, B. L., Carlsen, M. H., Phillips, K. M., Bohn, S. K., Holte, K., Jacobs, D. R., \& Blomhoff, R. (2006). Content of redox-active compounds (i.e., antioxidants) in foods consumed in the United States. American Journal of Clinical Nutrition, 84(1), 95-135. 
Halvorsen, B. L. \& Blomhoff, R.(2011). Validation of a quantitative assay for the total content of lipophilic and hydrophilic antioxidants in foods. Food Chemistry 127(2): 761768.

Hayes, W. A., Mills, D. S., Neville, R. F., Kiddie, J., \& Collins, L. M. (2011).

Determination of the molar extinction coefficient for the ferric reducing/antioxidant power assay. Analytical Biochemistry, 416(2), 202-205.

Huang, D. J., Ou, B. X., \& Prior, R. L. (2005). The chemistry behind antioxidant capacity assays. Journal of Agricultural and Food Chemistry, 53(6), 1841-1856.

Issopoulos, P. B., \& Salta, S. E. (1997). High-sensitive spectrophotometric determination of micromolar concentrations of D-Penicillamine by means of a coupled redox-complexation reaction. Farmaco, 52(2), 113-118.

Jimenez-Alvarez, D., Giuffrida, F., Vanrobaeys, F., Golay, P. A., Cotring, C., Lardeau, A., \& Keely, B. J. (2008). High-throughput methods to assess lipophilic and hydrophilic antioxidant capacity of food extracts in vitro. Journal of Agricultural and Food Chemistry, 56(10), 3470-3477.

Jubri, Z., Rahim, N. B. A., \& Aan, G. J. (2013 ). Manuka honey protects middle-aged rats from oxidative damage. Clinics 68(11): 1446-1454.

Kwakman, P. H. S, Velde, A. A. T., de Boer, L., \& Vandenbroucke-Grauls, Cmje Zaat, S. A. J. (2011).Two major medicinal honeys have different mechanisms of bactericidal activity. PLoS ONE 6(3): e17709. doi:10.1371/journal.pone.0017709 Retrieved August, 
2014, from

http://www.plosone.org/article/info\%3Adoi\%2F10.1371\%2Fjournal.pone.0017709.

Lampinen, J., Raitio, M., Perälä, A., Oranen, H., \& Harinen, R.-R. (2012). Microplate based pathlength correction method for photometric DNA quantification assay. Retrieved July, 2014, from http://www.thermoscientific.de/eThermo/CMA/PDFs/Various/File_60220.pdf.

Magalhaes, L. M., Segundo, M. A., Reis, S., \& Lima, J. L. (2008). Methodological aspects about in vitro evaluation of antioxidant properties. Analytical Chimica Acta, 613(1), 1-19.

Molan, P. (2008). An explanation of why the MGO level in manuka honey does not show the antibacterial activity. New Zealand Beekeeper 16(4),11-13. Retrieved Oct, 2014, from http://researchcommons.waikato.ac.nz/handle/10289/2142.

Moon, J. K., \& Shibamoto, T. (2009). Antioxidant assays for plant and food components. Journal of Agricultural and Food Chemistry, 57(5), 1655-1666.

Moniruzzaman, M., Sulaiman, S. A., Khalil, M. I. \& Gan, S. H. (2013 ). Evaluation of physicochemical and antioxidant properties of sourwood and other Malaysian honeys: a comparison with Manuka honey. Chemistry Central Journal 2013, 7:138

doi:10.1186/1752-153X-7-138 Retrieved August, 2014, from http://journal.chemistrycentral.com/content/7/1/138.

Owusu-Apenten, R. (2002). Food protein analysis: quantitative effects on processing. Boca Raton: CRC Press. 
Pulido, R., Bravo, L., \& Saura-Calixto, F. (2000). Antioxidant activity of dietary polyphenols as determined by a modified ferric reducing/antioxidant power assay. Journal of Agricultural and Food Chemistry, 48(8), 3396-3402.

Singleton, V.L., Orthofer, R., \& Lamuela-Raventos, R.M. (1999). Analysis of total phenols and other oxidation substrates and antioxidants by means of Folin-Ciocalteu reagent. . Methods in Enzymology 299, 152-178.

Smith, A. D., Morris, V. C., \& Levander, O. A. (2001). Rapid determination of glutathione peroxidase and thioredoxin reductase activities using a 96-well microplate format: Comparison to standard cuvette-based assays. International Journal for Vitamin and Nutrition Research, 71(1), 87-92.

Snow, M. J. \& Manley-Harris, M. (2004). On the nature of non-peroxide antibacterial activity in New Zealand Manuka honey. Food Chemistry 84(10), 145-147.

Sochor, J., Ryvolova, M., Krystofova, O., Salas, P., Hubalek, J. Adam, V., Trnkova, L., Havel, L., Beklova, M., Zehnalek, J., Provaznik, I., Kizek, R., . (2010). Fully automated spectrometric protocols for determination of antioxidant activity: advantages and disadvantages. Molecules 15(12), 8618-8640; doi:10.3390/molecules15128618 Retrieved Oct, 2014, from http://www.mdpi.com/1420-3049/15/12/8618.

Stratil, P., Klejdus, B., \& Kuban, V. (2006). Determination of total content of phenolic compounds and their antioxidant activity in vegetables - Evaluation of spectrophotometric methods. Journal of Agricultural and Food Chemistry, 54(3), 607-616. 
Tsao, R., Yang, R., \& Young, J. C. (2003). Antioxidant isoflavones in Osage orange, Maclura pomifera (Raf.) Schneid. Journal of Agricultural and Food Chemistry, 51(22), $6445-6451$.

Weston, R. J. (2000). The contribution of catalase and other natural products to the antibacterial activity of honey: a review. Food Chemistry 71(2), 235-239. 


\section{Table and Figure legends}

Table 1 Calibration parameters for the microplate based FRAP assays before and after pathlength correction

Table 2 Total antioxidant capacity (FRAP value) and total phenols content of Manuka honey according to their UMF rating

Figure 1: The predicted optical pathlength for a microplate reader according to filling volume of fluid $\left(\mathrm{cm}^{-3}\right)$ for cylindrically-shape wells and a diameter $=0.689 \mathrm{~cm}$ and 0.635 $\mathrm{cm}$ at the top and bottom. The graph gradient is $2.90 \mathrm{~cm}^{-2}$ (see text for details)

Figure 2: Calibration graphs for microplate-FRAP assays for gallic acid, ascorbic acid or ferrous ammonium sulphate. Solutions (20ul) and $280 \mu$ FRAP solutions were reacted in 96-well microplate and A593 was recorded with a plate reader. 
Figure 1

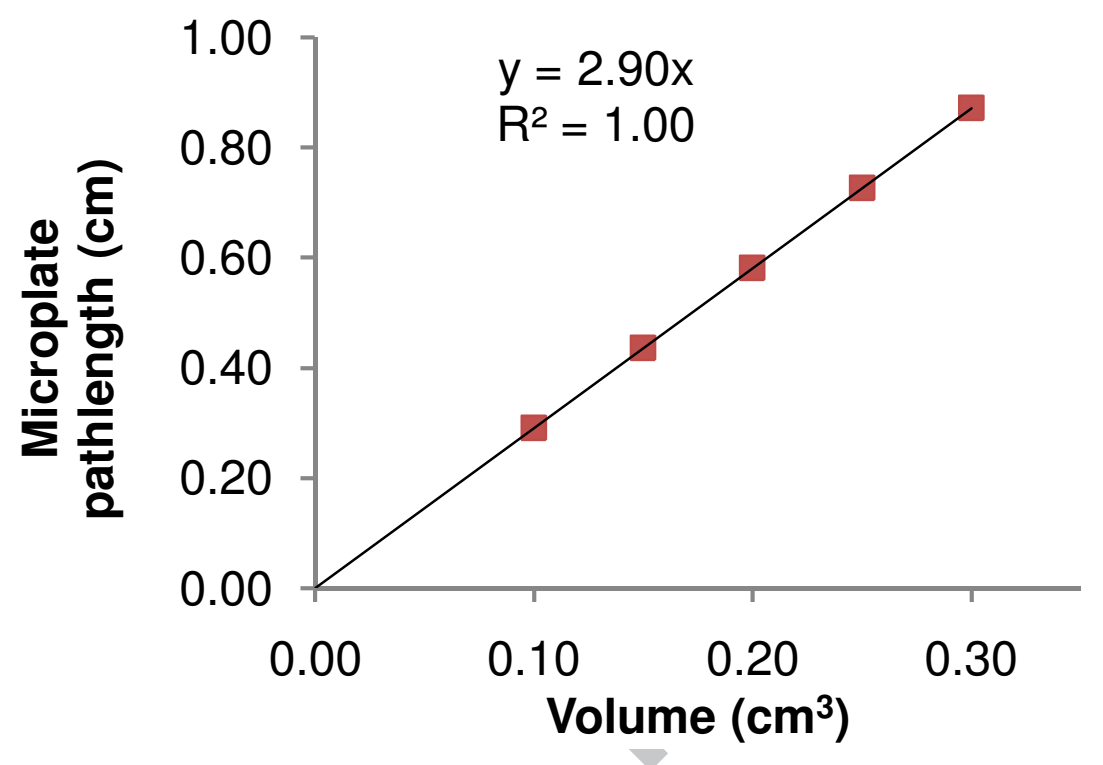


Figure 2

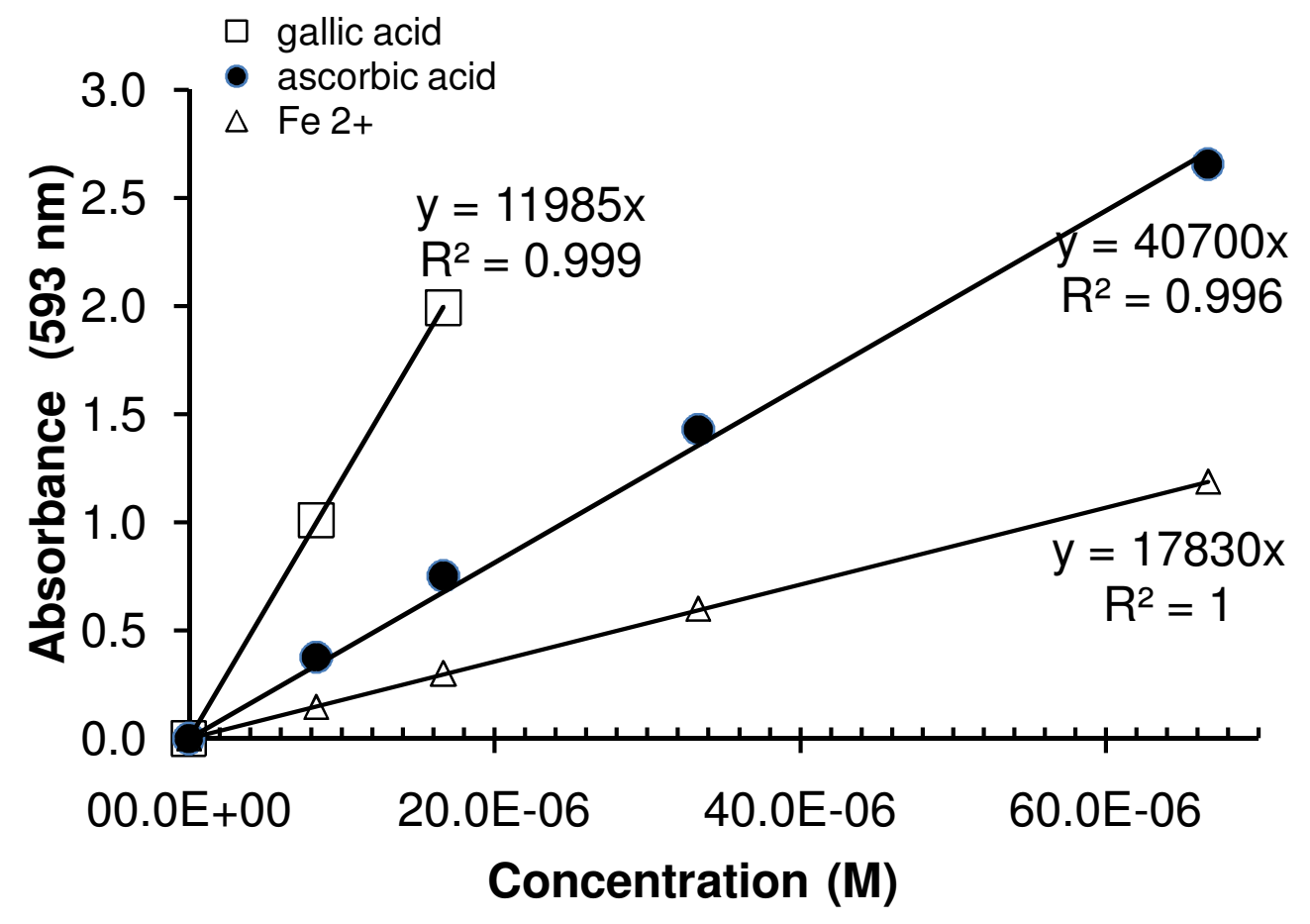


FOODCHEM-D-14-03339 -revised

\section{Tables}

Table 1: Calibration parameters for the microplate FRAP assays before and after pathlength correction

\begin{tabular}{lllll}
\hline Calibrant & \multicolumn{1}{c}{$\begin{array}{c}\text { Sensitivity } \\
\text { mFRAP1 }\end{array}$} & $\begin{array}{c}\text { MDC } \\
\text { mFRAP1 }\end{array}$ & $\begin{array}{c}\text { Sensitivity } \\
\text { mFRAP2 }\end{array}$ & $\begin{array}{c}\text { MDC } \\
\text { mFRAP2 }\end{array}$ \\
\hline Gallic acid & $70557( \pm 1243)$ & $2.3 \times 10^{-7}$ & $115704( \pm 1351)$ & $8.7 \times 10^{-8}$ \\
Gallic acid & 143993 & $1.1 \times 10^{-7}$ & 139402 & $7.2 \times 10^{-8}$ \\
Asc. acid & $25491( \pm 135)$ & $5.8 \times 10^{-7}$ & $38706( \pm 763)$ & $1.2 \times 10^{-7}$ \\
Asc. acid & 52022 & $2.8 \times 10^{-7}$ & 46634 & $9.6 \times 10^{-8}$ \\
AFS & $10509( \pm 46)$ & $5.1 \times 10^{-7}$ & $18065( \pm 36)$ & $2.5 \times 10^{-7}$ \\
AFS $^{*}$ & 21447 & $2.5 \times 10^{-7}$ & 21765 & $2.1 \times 10^{-7}$ \\
\hline
\end{tabular}

Notes: Assay sensitivity is equal to the molar absorptivity, $\varepsilon_{\mathrm{M}}\left(\mathrm{M}^{-1} \mathrm{~cm}^{-1}\right) . \mathrm{MDC}=$ minimum detectable concentration, AFS = ammonium ferrous (II) sulphate, Asc. Acid = Ascorbic acid, ( $\left.{ }^{*}\right)$ Data with pathlength corrections for mFRAP1 ( $L^{\prime}=0.49 \mathrm{~cm}$ for $200 \mu \mathrm{l}$ sample) and mFRAP2 ( $L^{\prime}=0.83 \mathrm{~cm}$ for $300 \mu$ sample). 
Table 2 FRAP value and total phenols content of Manuka honey related to UMF rating

\begin{tabular}{|c|c|c|c|}
\hline $\begin{array}{l}\text { UMF } \\
\text { Rating }\end{array}$ & $\begin{array}{c}\text { FRAP } \\
\left(\mu \mathrm{M} \mathrm{Fe} e^{2+} / 10 \% \text { honey }\right)^{a}\end{array}$ & $\begin{array}{c}\text { FRAP } \\
\left(\mathrm{mmol} \mathrm{Fe}{ }^{2+} / 100 \mathrm{~g}\right)^{b}\end{array}$ & $\begin{array}{l}\text { Total phenol } \\
(\mathrm{mg} \mathrm{GAE} / \mathrm{kg})^{\mathrm{c}}\end{array}$ \\
\hline- & $197( \pm 62)$ & $0.20( \pm 0.061)$ & $208( \pm 20)$ \\
\hline 5 & $545( \pm 123)$ & $0.54( \pm 0.123)$ & $372( \pm 22)$ \\
\hline 10 & $611( \pm 93)$ & $0.61( \pm 0.093)$ & $453( \pm 16)$ \\
\hline 15 & $677( \pm 78)$ & $0.68( \pm 0.077)$ & $524( \pm 24)$ \\
\hline 18 & $756( \pm 81)$ & $0.76( \pm 0.081)$ & $576( \pm 20)$ \\
\hline
\end{tabular}

Notes: Values are means $( \pm S D)$ of eight determinations. UMF is Unique Manuka factor, FRAP value is expressed (a) as $10^{-6} \mathrm{M}$ Fe (II) reduced by $10 \%$ solution of honey or (b) as $10^{-3}$ moles Fe (II) reduced per $100 \mathrm{~g}$ of honey; (c ) total phenols was determined by Folin method is expressed as mg-Gallic Acid Equivalents (GAE). Values in all columns are significantly different by ANOVA $(p<0.05)$. 


\section{Highlights}

Universal calibrations for microplate FRAP assays Simplified pathlength corrections for microplate FRAP assay Microplate assay for total antioxidant capacity 